\title{
Defining the Industrial and Engineering Management Professional Profile: a longitudinal study based on job advertisements
}

\author{
Rui Manuel Lima ${ }^{\text {a* }}$, Diana Mesquita ${ }^{\mathrm{b}}$, Carla Rocha ${ }^{\mathrm{a}}$, Mauro Rabelo ${ }^{\mathrm{c}}$ \\ ${ }^{a}$ Centro Algoritmi, Production and Systems Engineering, University of Minho, Guimarães, Portugal \\ ${ }^{b}$ Research Centre on Child Studies, University of Minho, Braga, Portugal \\ 'Department of Mathematics, University of Brasília, Brasília, Brazil \\ *rml@dps.uminho.pt
}

\begin{abstract}
The engineering professional profiles have been discussed by several branches of the engineering field. On the one hand, this discussion helps to understand the professional practice and contributes to the specification of the competences that are suitable for each function and company culture. On the other hand, it is an essential starting point for the definition of curricula in engineering schools. Thus, this study aims to characterize, in an innovative way based on job advertisements, the demand for competences and areas of practice for Industrial Engineering and Management contributing for the definition of a professional profile. This characterization is based on the analysis of 1391 job advertisements, collected during seven years from a Portuguese newspaper. The data analysis takes into account the job description in which two categories were considered: areas of professional practice (e.g. project management) and transversal competences (e.g. teamwork). Considering the total number of job advertisements, it was possible to identify 1,962 cumulative references for 11 professional practice areas and 5,261 cumulative references for transversal competences. The contribution of this study lies on the identification of the main areas of practice and the main transversal competences demanded by employers.
\end{abstract} Keywords

Industrial Engineering and Management. Professional profile. Areas of professional practice. Transversal competences. Job advertisements. University-business cooperation.

How to cite this article: Lima, R. M., Mesquita, D., Rocha C., \& Rabelo M. (2017). Defining the Industrial and Engineering Management Professional Profile: a longitudinal study based on job advertisements. Production, 27(spe), e20162299. http://dx.doi.org/10.1590/0103-6513.229916

\section{Introduction}

Universities and business organizations are both responsible for the formation of the engineering professionals. However, in the majority of times, both act independently. Universities tend to act focusing on the initial education of engineers, whereas business organizations generally act focusing on the training of the required competences for their functions and procedures of specific needs. The scenario is one in which universities, based mainly on the way academics see the profession, adopt an education model focused on knowledge transmission instead of focusing on the development of competences. Hence, Higher Education institutions have been constantly criticized for not preparing graduates for the demands of professional practice (Knight \& Yorke, 2004). Furthermore, the young engineers hired by business organizations, although highly knowledgeable, might present a lack of professional competences. In order to bridge this gap, universities and business organizations have a joint responsibility to approach and particularly to cooperate on the development of professionals creating a profile aligned with the professional practice demand. 
In Europe, for instance, employment is in the center of the concerns of the political strategies for the development of employability achievements. Yorke $(2004$, p. 8$)$ presents the following definition for employability:

Employability is taken as a set of achievements - skills, understandings and personal attributes - that makes graduates more likely to gain employment and be successful in their chosen occupations, which benefits themselves, the workforce, the community and the economy.

Based on the previous definition one can argue that universities have an important role in the formation of students, who are capable to add value in industries and in society.

One of the European initiatives in this regard has been the creation of the annual University-Business Forum that approaches higher education institutions, companies, business associations, intermediaries and public authorities since 2008. This Forum provides the opportunity for interaction between these stakeholders, for dialogue, networking, and the exchange of good practices. As a result of these initiatives, a University-Business Cooperation information portal has also been created (University-Business Cooperation, 2017). Moreover, all these initiatives are structurally supported by the European Union (European Commission, 2007): "Universities must also provide knowledge and skills geared to the needs of the labor market. In other words, graduates' qualifications must meet the needs of the labor market". In other parts of the globe, there is also an increasing social/political interest in matching professional needs with the educational process. A study on UniversityBusiness cooperation in the US and Canada showed that among the 4 most important reasons for engaging in University-Business interactions is the possibility to find "training of students for the professional environment" and "providing employment" (Ranga et al., 2013, p. 7). Furthermore, the US government launched the "Skills for America's Future" initiative to build "[...] partnerships with industry, labor unions, community colleges and other training providers [...]" in order to develop a workforce with professional competences (Sabochik, 2010). Even though there are numerous examples of initiatives and studies about university and business collaboration, there is a lack of studies focusing in collaboration from the point of view of education. According to Healy et al. (2014, p. 5),

[...] this is unfortunate as it is through people, as students, graduates and employees, that knowledge exchange can often most effectively be embedded in both universities and businesses, relevant skills developed and the conditions for future innovation and economic growth laid.

The alignment between initial formation and professional practice demands studies that are able to identify the competences which are useful for professionals. This identification can support the delivery of useful concepts, tools and frameworks for the development of curricula, which can help to bridge the existing gap. One of the larger studies about "student employability profiles" presents competences for a large set of professional areas, including Engineering as a whole (Rees et al., 2006). Nevertheless, the need of studies on more specific professional areas, particularly different Engineering areas are required.

For that reason, this paper will focus on a specific engineering field that can be identified by several names, used to describe similar or overlapping professional areas of practice, namely: Industrial Engineering, Industrial Engineering and Management, Industrial Management and Engineering, Industrial and Engineering Management, Engineering Management, Production Engineering, and Manufacturing Engineering. Elrod et al. (2010) referring to Engineering Management, reported that this area of professional practice is not well understood by engineering professionals, students and academics. However, this work does not have the purpose of discussing the differences between these denominations, and therefore the term Industrial Engineering and Management (IEM) will be used as involving a broad spectrum of professional practice of engineers. IEM is seen in this work as the engineering field related to the design, improvement and management of systems composed by people, materials, equipment, financial resources, information and energy, that deliver products and services (APICS, 2009; Institute of Industrial Engineers, 2012).

The identification of the "skills, understandings and personal attributes" (Yorke, 2004), i.e. resources, required by the professional practitioners can be used to develop curricula and to apply learning strategies that will contribute for augmenting the employability of IEM engineers. Competences gain a meaning when persons mobilize resources on specific professional scenarios (Le Boterf, 1997; Perrenoud, 2004; Zarifian, 2001), which are determined by the professional function and the required knowledge area (Mesquita et al., 2015). As an example, it is possible to imagine an IEM professional, that acting as an Industrial Manager, must be able to design production systems. This engineer must apply his/her competence to design production systems that, in most situations, should be mobilized using tacit knowledge from production systems design (e.g. production cells or line); however, in some situations, knowledge from ergonomics should also be mobilized. These technical 
competences are described in different studies as core (Yorke, 2004) or subject specific (González \& Wagenaar, 2007).

In the same professional scenario described above, an IEM professional should be able to operate the production system (e.g. production cell), integrating a team of people to work in that cell. In this case, he/she should be able to apply leadership and teamwork competences in order to develop the most of that production system. These transversal competences are described in several works as transferable (Yorke, 2004), general (Mertens, 1996), generic (González \& Wagenaar, 2007) or soft skills (Ramesh, 2010).

In summary, the professional profile can be described by three dimensions, namely: competences, knowledge areas and functions. Function is the term chose to describe specific behaviors expected by a professional when performing the work that he or she is responsible for. In the examples above, design production systems is an example of a function. Knowledge areas are a form of classification about the main areas a professional should have knowledge in order to be able to perform the functions of his/her profession. Thus, despite the fact that these three dimensions are part of the professional profile, and therefore part of the practice, the classification of different areas of practice demanded by business organizations can be made using knowledge areas.

This study intends to contribute for the definition of IEM professional profile, using an innovative approach based on job advertisements for characterization of the demand of professional areas of practice and transversal competences, considering the perspectives of business organizations. Although there are some studies dedicated to IEM profession intending to analyze these kind of dimensions, they use surveys to get perceptions from the professionals (Meier et al., 2000; Sageev \& Romanowski, 2001; Scott \& Yates, 2002). Therefore, a different methodological approach is proposed and presented in this work, which brings a new contribution to identify industry needs. It reports on a longitudinal research during seven years, based on data from job advertisements for IEM from the weekly edition of Expresso, a Portuguese national newspaper with a circulation of over 95000 copies per weekly issue (Expresso, 2015). The contribution of this study lies in the overview of the demands for IEM that allows professionals to improve their understanding of the profession and how different areas of practice and transversal competences are demanded over the years.

\section{Implications for Industrial Engineering and Management Professionals}

Companies will achieve their own potential if they have the people with the right competences who fit in their culture (CEDEFOP, 2012). Therefore, industry companies need to hire IEM professionals who have competences aligned with the requirements imposed by the functions of their responsibility. So, all over the world, companies and engineering schools are interested in reducing the gap between the education output and the professional input needs. In order to achieve this, different approaches can be followed, such as having industrial consultative committees, having meetings with industrial representatives, gathering information from alumnae associations, and sending questionnaires to companies. All these methods have their own complementary role in this process. According to Linton (2015), job advertisements have a typical set of sections: information about the job and its responsibilities, required and desirable candidate profile, company information, salary and benefits and application process. The analyses of the first two types of sections referred above, in job advertisements of a specific professional area, make possible to identify the main areas of practice that are requiring new candidates, and the main transversal competences that companies are looking for when hiring.

Assuming that a company wants to be effective in the hiring process, their job advertisement should be as accurate as possible in the definition of a suitable profile and the areas of practice. In addition, they should use a few amount of newspaper space, and focus on the main required attributes of the profile. Therefore, considering the information included in job advertisements, engineering schools can create a picture of the companies' needs getting the opportunity to align teaching and learning strategies that take into account contexts from professional practice, encompassing the identity of an engineer as a whole. Thus, companies can hire graduates more aligned with their needs and expectations. This work can also be used by students to choose professional paths during their training, as well as by the professionals to develop their own continuous education paths.

From another perspective, the companies can use this information to compare their hiring processes with the overall picture of job offers in IEM. In this way, the practicing professionals could create job advertisements described in a more standardized way that can make it easier to match their needs with those of the candidates'. Furthermore, it is possible to identify the trends of IEM, taking into account the growth of the areas over the time, including emerging areas.

In short, the data of this study provides important input for following trends on professional practice and transversal competences needs in the IEM field and universities can use this information as input to rethink the effectiveness of their teaching and learning approaches. 


\section{Competences development and the professional practice}

The formation of engineering students must consider what the professional practice is requiring, in order to bridge a gap between competences that universities are providing and competences that societies, industries and services are demanding, as described in several studies (Biesma et al., 2008; Heijde \& Van Der Heijden, 2006; Hennemann \& Liefner, 2010; Jackson, 2012; Marie-Emmanuelle et al., 2010; Markes, 2006; Mason et al., 2009; Stiwne \& Jungert, 2010; Walther et al., 2011). In order to reduce this gap, the learning process requires innovative approaches contributing for the development of competences. This idea is reinforced in the report of Engineering Education from UNESCO (United Nations Educational, Scientific and Cultural Organization, 2010, p. 32):

University courses can be made more interesting through the transformation of curricula and pedagogy using such information and experience in more activity - project and problem-based learning, just-in-time approaches and hands-on application, and less formulaic approaches that turn students off. In short, relevance works! [...] The future of the world is in the hands of young engineers and we need to give them as much help as we can in facing the challenges of the future.

Engineering students need meaningful learning situations to develop competences that will allow them to transfer them to other contexts, specifically into professional practice. For example: let's say the teacher challenges the students with a task based on teamwork; those students will have the opportunity to interact with each other, they will need to manage conflicts, make decisions, manage time, and many other processes that teamwork involves. Learning experiences achieved from these processes allow students to transfer competences developed in this situation to similar ones. This is the main principle needed to understand the differences between competences and other terms embedded in the literature, such as objectives, abilities, or skills. Competence encompasses the mobilization of different resources (e.g. previous experiences, values, knowledge) in specific contexts, during the educational process or in professional practice.

Within IEM context, students need to develop a set of competences to be mobilized in different professional areas, with a very large number of diverse functions related with production and service systems. Omurtag (2009, p. 1) reinforces this idea stating that in engineering management

[...] graduates can design, establish, operate, optimize, and continuously improve a technological enterprise, public or private, for profit or not for profit. In summary they are enterprise engineers doing managerial engineering work.

For illustration purposes, a few functions can be referred: production systems design, production planning, ergonomics analysis and design, project management and team leader. For instance, Kotnour \& Farr (2005) made a contribution for the body of knowledge of the engineering management discipline, based on the analysis of the contributing disciplines, professional societies, journals, and conferences. These authors proposed a framework with the following 14 areas of knowledge: New Product / Technology Development, Value Chain Management, Production, Technology Marketing, Strategic Management, Project/Program Management, Systems Engineering, Knowledge Management, Change Management, Organizational and Workspace Design, Economics of Engineering, Quantitative Methods and Models, Quality Management, Developing Engineering Management Professionals.

In fact, knowledge is not enough for professional practice, and transversal competences are quite relevant (Becker, 2006; Hattum-Janssen \& Mesquita, 2011; Moesby, 2005; Nair et al., 2009; Passow, 2012; Pesches \& Reindel, 1998; Tymon, 2013). As mentioned earlier, the literature refers to transversal competences in different ways, "generic", "transferable”, “dynamic” (Halász \& Michel, 2011). Transversal competences refer to those competences that are beyond technical subjects but are also related to professional practice.

There is a concern to develop IEM programs that include transversal competences in the curriculum planning. One of the evidences is the accreditation criteria used in US and in Europe. On the one hand, the US Accreditation Board for Engineering and Technology (ABET) defines student outcomes that includes transversal competences, namely: the ability to analyze and interpret data; the ability to function on multidisciplinary teams; the ability to identify, formulate, and solve engineering problems; the ability to understand professional and ethical responsibility; the ability to communicate effectively; the ability to understand the impact of engineering solutions in a global, economic, environmental, and societal context; the ability to engage in life-long learning; the knowledge of contemporary issues; the ability to use the techniques, skills, and modern engineering tools necessary for engineering practice. On the other hand, the European Network for Accreditation of Engineering Education (ENAEE), includes these transversal competences in the accreditation process: to function effectively as an individual, as a member of a team and as a leader; use diverse methods to communicate effectively in 
national and international contexts; commit to professional ethics, responsibilities and norms of engineering practice; demonstrate an awareness of project management; recognize the need for, and have the ability to engage in independent, life-long learning.

Considering the need to develop transversal competences, El-Baz \& El-Sayegh (2010) developed a model encompassing a list of 24 competences for Engineering Managers for a better understanding of the Engineering Management field, which was tested in the United Arab Emirates (UAE). The six that were considered the most important for UAE academics and professionals of Engineering Management were: vision and strategic thinking, truthfulness and integrity, mentoring and coaching others, markets and marketing, enthusiasm and inspiration and budget and finance.

One of the main questions that are possible to consider is: "How can these competences be properly developed in the curriculum?" One possible answer is given by the UNESCO report mentioned before: "[...] using such information and experience in more activity - project and problem-based learning, just-in-time approaches and hands-on application" (United Nations Educational, Scientific and Cultural Organization, 2010, p. 32). Some programs in IEM focused on active learning methodologies, such as Project-Based learning based on real problems from industry (Lima et al., 2014), games in product development (Yalabik et al., 2012), hands-on activities (Santos et al., 2012), and Problem-Based Learning to work concepts related to Enterprise Resource Planning (ERP) systems (Léger et al., 2012).

Such approaches that allow the engagement of students in the learning process create the opportunity for students to research information, find problem solutions by themselves, interact with the teacher, who now acts as a facilitator, and not as an ordinary knowledge transmitter. This approach also focuses on a deeper learning process, in which students seek to understand the subjects, motivated and engaged in their own learning process, relating different ideas with their previous knowledge. In this way, students develop new knowledge and competences, establishing links between theory and practice (Biggs \& Tang, 2011).

In this sense, the relation between education and professional practice must be understood, in order to provide learning situations and to create opportunities for students to develop competences that are demanded in professional practice. This study points out a strategy to identify transversal competences and areas of practice, considering the demands for IEM.

\section{Methodology}

As referred in the introduction, this study aims to present a contribution for the definition of the professional profile, based on an overview about the demands for IEM, analyzing areas of professional practice and transversal competences identified in seven years of job advertisements. This is a descriptive study that, by definition, intends to portray a situation in order to develop a better understanding about it. In other words, this approach provides an overall picture of the subject analyzed (Sampieri et al., 2006). Additionally, this study adopts a longitudinal strategy collecting information during seven consecutive years, which strengthens the description and interpretation of the context. The methodology used in this work was based on a set of steps proposed by Sampieri et al. (2006) for qualitative studies: collect and revise data (1), make the analysis of the data, based on different codifications (2) and finally make the interpretation of the data (3). Steps 1 and 2 are described in detail in the following paragraphs and step 3 is presented in the next section.

The data collection aims to identify the areas of professional practice as well as transversal competences that are required by hiring/recruiting organizations for IEM. The data collection was based on document analysis, aiming to create a perspective that provides a broader vision about these requirements. Thus, job advertisements were collected from one of the leading Portuguese newspaper, considering a period of seven years (2007-2013).

The analysis focused on the description of each job advertisement that presented a position and function related to IEM practice. The procedure of analysis depended on the content of the job advertisements, which presented different shapes and settings, with more or less detail. The data was analyzed through the content from the job advertisements, which implies an organization of the information by transforming keywords into units of analysis, using categories that represents the conceptual framework (Esteves, 2006).

A rigorous content analysis (Bardin, 2006; Miles \& Huberman, 1994), developed in three stages, required a conceptual framework. In a first stage the information was analyzed considering two broad categories: areas of professional practice and transversal competences. The selection of these categories was based on different sources of engineering education literature (ABET, 2013; Becker, 2006; Buzacott, 1984; EUR-ACE, 2008; Matson et al., 2007; Moesby, 2005; Nair et al., 2009; Pesches \& Reindel, 1998; United Nations Educational, Scientific and Cultural Organization, 2010; Zandin, 2001). The Engineering Report from UNESCO (United Nations Educational, Scientific and Cultural Organization, 2010) highlighted the importance to understand what is 
engineering and what engineers do. Based on this purpose the areas of professional practice were considered as one of the categories of analysis, and transversal competences as another category. Other information presented in the job advertisement was not considered for this study, such as age, required professional experience, and wage amongst other requirements.

The second stage focused on the definition of the areas of professional practice for IEM. Functions are seen in this work as the actions for which an IEM professional is specially fitted. These can be identified and analyzed from job advertisements, and are closely linked with areas of knowledge. In fact, we used a classification of areas of knowledge as the same to classify the areas of practice. Thus, we identified the demand for functions in job advertisements and cross-matched them with a set of previously defined areas of knowledge (Lima et al., 2012). First a set of a prior knowledge areas typically included in the IEM field was identified, based on a selected body of literature (Buzacott, 1984; Elsayed, 1999; Emerson \& Naehring, 1988; Gallwey, 1992; Zandin, 2001). The literature analysis revealed some knowledge areas, which were commonly found in different sources, and that could be considered to be representative of current IEM field. A deeper review of the literature sources led to a set of four references that were the base for the definition of the IEM Specific Areas of Knowledge used in this work: Kuo (2001), Hicks (2001), Fraser \& Teran (2006), Matson et al. (2007). These knowledge areas were crossed with the job advertisements text to build the definition of 11 professional practice areas (PPA\#) considered in this work and referred with the following terms: Production Management, Automation, Quality, Economics Engineering, Marketing, Industrial Optimization, Ergonomics and Human Factors, Supply Chain Management, Maintenance, Project Management, and Product Design. Table 1 presents the definitions used in this work for these areas.

Table 1. Definition of the professional practice areas.

Area Definition

Automation

In the industrial Automation area of practice, engineers should troubleshoot, repair and maintain automated industrial equipment, such as computer numerical control (CNC) equipment and robots (Groover, 2015; Study.com, 2016).

Economics Engineering

The application of economic principles in the engineering problem by solving process; for example, analysing the economics of different alternatives, analysing industrial costs and being involved in the financial management of organizations (Watts \& Chapman, 2016).

"Ergonomics (or human factors) is the scientific discipline concerned with the understanding of interactions among humans and other elements of a system, and the profession that applies theory, principles, data,

Ergonomics and Human Factors and other methods to design in order to optimize human well-being and overall system performance" (International Ergonomics Association, 2016).

Supply Chain Management

"The design, planning, execution, control and monitoring of supply chain activities with the objective of creating net value" for industrial and service companies (APICS, 2013d).

Maintenance Management process of organization, planning and implementation of corrective maintenance, preventive maintenance, and continuous improvement of industrial and service business organizations (IDCON, 2016). Industrial optimization make a link between mathematics, engineering and management, using as

Industrial Optimization operations research, heuristics or simulation, for achieving the best possible solution for a problem for industrial and service companies, in terms of a specified objective (APICS, 2013c; Bangert, 2012).

"The conversion of a need or innovation into a product, process, or service that meets both the enterprise

Product Design and customer expectations. The design process consists of translating a set of functional requirements into an operational product, process or service” (APICS, 2013a; Dym et al., 2014).

Design, improvement and management of systems that deliver products and services. This area is related with the design and improvement of production systems and the activities of production planning and control activities for the efficient and effective use of those production systems (Halevi, 2001; MartinVega, 2001; Vollmann et al., 2005).

Production Management Application of "knowledge, skills, tools, and techniques to project activities to meet the project

Project Management requirements" (Project Management Institute, 2013, p. 6).

Quality "The analysis of a manufacturing system at all stages to maximize the quality of the process itself and the products it produces" (American Society for Quality, 2016).

Marketing

"The design, pricing, promotion, and distribution of goods to create transactions with businesses and consumers" (APICS, 2013b).

As an illustration of the procedure of classification, the practice areas of the following two job advertisements from December 2013 were classified as Supply Chain Management and Product Design:

Logistics and customer manager. Develop a commercial activity of prospecting clients and management of the existing portfolio as well as installation and monitoring of logistics operations with customers. Job Advertisement 201312.A. 
Process engineer. Influence the design of final products, ensuring the conditions of the proposal. Design, implementation of equipment and tools in order to avoid risks of security, quality and productivity. Cost-benefit analysis and preparation of data reports in order to lead to process improvements. Troubleshooting and detailed analysis of manufacturing processes. Job Advertisement 201312.B.

Regarding transversal competences, a different process was used, based on the job advertisements text. In this procedure, the researchers did not use a pre-selected list and made the option to use an emergent classification. Thus, a large set of 26 transversal competences (TRC\#) emerged from the job advertisements text analysis: Foreign Languages; Information and Communications Technology (ICT); Teamwork; Communication; Leadership; Planning / Organization; Initiative; Dynamism; Interpersonal relationship; Autonomy / Liability; Goal orientation; Analytical \& Research Skills; Negotiation; Problem solving; Motivation; Ability to adapt; Entrepreneurship; Dealing with pressure and stress; Critical thinking; Creativity; Openness to learning; Accuracy / Rigor / Exactness; Strategic Vision; Self-reliance; Maturity; Ethics.

It should be noted that these emergent competences are stated mainly as used in the job advertisements. Even though the complete definition of the whole set of transversal competences is outside of the scope of this research work, there were discussions to create a common understanding of the competences definitions. As an example, the job advertisement number 10 from January 2013 requires a candidate that is "dynamic", "has initiative" and "is able to work in teams", and a direct classification was made for these three competences. In some specific cases, namely in the job advertisement number 2 from January 2012, it was necessary to make a classification by approximation: "assertiveness" was classified as communication, "resolution" was not classified; "leadership" and "teamwork" were directly classified; and "proactivity" was classified as initiative. As an example, in this work "communication" is considered as the ability to share information both oral and written in such a way that the receiver understands the information. The way the communication is developed can be classified as assertive, aggressive, manipulative or passive. The IEM professionals must be able to do this in different contexts with persons with rather different roles in companies.

The third stage of the study included a review of the analysis made by three researchers involved in the study. The researchers were trained to make the classification based on a set of at least 3 months of job advertisements. For the classification process, every classification made by a researcher was reviewed by at least another researcher. If there were any divergences, then the researchers would discuss and seek for consensus, thus ensuring a deep reflexive analysis and the validation of the results.

This conceptual framework was used to identify both the professional practice areas and the transversal competences most required. Table 2 presents a quantitative summary of the analyzed data, showing that in a total number of 1,391 job advertisements, it was possible to identify 1,962 cumulative references for professional practice areas and 5,261 cumulative references for transversal competences.

Table 2. Job advertisements data - quantitative summary.

\begin{tabular}{lcccccccc}
\hline \multicolumn{1}{c}{ Years of Analysis } & 2007 & 2008 & 2009 & 2010 & 2011 & 2012 & 2013 & Total \\
\hline Job advertisements & 89 & 249 & 213 & 321 & 261 & 149 & 109 & 1,391 \\
Professional practice areas & 151 & 359 & 304 & 487 & 365 & 181 & 115 & 1,962 \\
Transversal competences & 360 & 1,034 & 890 & 1,177 & 902 & 532 & 366 & 5,261 \\
\hline
\end{tabular}

\section{Findings}

The broad nature of IEM is a feature recognized by professionals that makes it difficult to fully understand the professional practice and the impact of different areas and competences on the demand of employers. As a contribution for clarifying this understanding, the authors conducted a process of content analysis of job advertisements, quantifying the frequency of occurrences of Areas of Professional Practice and Transversal Competences.

\subsection{Areas of professional practice}

The references to areas of professional practice in the 1,391 job advertisements were analyzed considering a framework of classification presented above. The job advertisements were classified as predominantly belonging to one or more specific areas, depending on the function title and description. The analysis of the identified 1,962 professional practice areas, represented in graph of Figure 1, shows that the great majority (31.8\%) of job advertisements are related with activities of production management, which is followed by a set of professional 


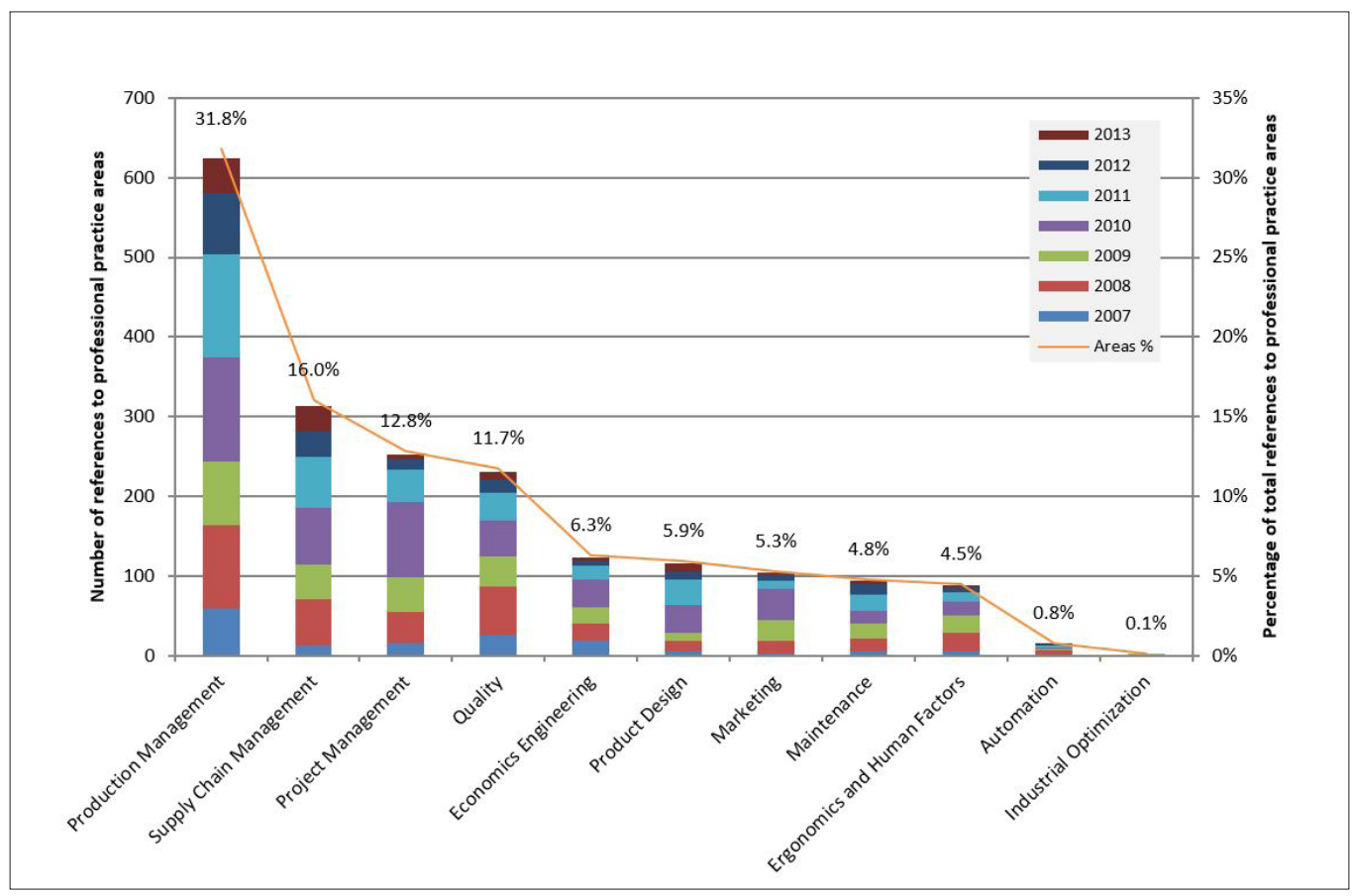

Figure 1. Job advertisements analysis: professional practice areas.

practices areas with frequency of occurrence ranging between 10 and 20 percent: Supply Chain Management (16.0\%), Project Management (12.8\%) and Quality (11.7\%). The measures presented in "Areas \%" in Figure 1 have a margin of error from $\pm 0.1 \%$ to $\pm 2.1 \%$, respectively from Industrial Optimization to Production Management, with a confidence level of $95 \%$.

At the opposite position in the graph, it is possible to identify an almost non-existent reference to Industrial Optimization or Automation in the IEM job advertisements. This shows that employers do not make explicit references to Industrial Optimization or Automation in job advertisements. Despite the fact that there is not enough evidence to understand the reasons for this, it could be argued that employers may expect professionals to master the main techniques of these areas, when hiring for other areas. Explaining the low occurrence of these two areas could be the base for other studies.

Regarding the variation of the demand during the seven years, it was possible to verify that the variation of percentage was not significant and that the higher standard deviations could be calculated in the first four areas of professional practice, respectively: $0.060,0.056,0.045$, and 0.035 . The greater difference between the maximum and minimum percentages could be identified in "Supply Chain Management" (20.1\%), followed by "Production Management" (16.6\%) and Project Management (15.0\%).

With the purpose of analyzing the evolution, the ranking of all areas in each year was computed and presented in Table 3. The ranking shows the relative position of each area to the others. The area with a high number of cumulative references has rank 1 and the area with lower number of references has rank 11 . The ranking is highly sensible to small variations, even though it revealed some interesting results that were not possible to interpret by the direct analysis of the evolution of the seven years demand. The ALL variable represents the rank position considering all job advertisements during the seven years. The AVR represents the average of ranks and SD the standard deviation for the seven years data. The variables MIN and MAX represents the minimum and maximum ranks and DIFF the difference between MAX and MIN.

The higher variation can be found in the following areas that have variations of 4, 5 or 6 positions (DIFF) during the 7 years: Economics Engineering, Product Design, Marketing, Maintenance and Ergonomics and Human Factors. The most significant positive evolutions can be seen in "Product Design" and "Maintenance" areas, respectively in positions 3 in 2013 and 4 in 2012.

Different institutions and graduates can have different profiles, stronger in specific areas, and all profiles are useful. This analysis shows that even though there is a stronger demand in some specific areas, other areas are also demanded, and the evolution along the years contributes to understand this engineering field and the variation of emphasis over the time. 
Table 3. Ranking of professional practice areas.

\begin{tabular}{|c|c|c|c|c|c|c|c|c|c|c|c|c|c|}
\hline Number of job advertisements & 89 & 249 & 213 & 321 & 261 & 149 & 109 & & & & & & \\
\hline Number of cumulative references & 151 & 359 & 304 & 487 & 365 & 181 & 115 & & & & & & \\
\hline Areas ranking & 2007 & 2008 & 2009 & 2010 & 2011 & 2012 & 2013 & ALL & AVR & SD & MIN & MAX & DIFF \\
\hline Production Management & 1 & 1 & 1 & 1 & 1 & 1 & 1 & 1 & 1.0 & 0.000 & 1 & 1 & 0 \\
\hline Supply Chain Management & 4 & 3 & 3 & 3 & 2 & 2 & 2 & 2 & 2.7 & 0.700 & 2 & 4 & 2 \\
\hline Project Management & 3 & 4 & 2 & 2 & 3 & 4 & 5 & 3 & 3.2 & 1.030 & 2 & 5 & 3 \\
\hline Quality & 2 & 2 & 4 & 4 & 4 & 3 & 3 & 4 & 3.1 & 0.833 & 2 & 4 & 2 \\
\hline Economics Engineering & 3 & 6 & 7 & 7 & 7 & 8 & 6 & 5 & 6.3 & 1.485 & 3 & 8 & 5 \\
\hline Product Design & 6 & 9 & 9 & 6 & 5 & 6 & 3 & 6 & 6.3 & 1.979 & 3 & 9 & 6 \\
\hline Marketing & 9 & 7 & 5 & 5 & 9 & 7 & 8 & 7 & 7.1 & 1.552 & 5 & 9 & 4 \\
\hline Maintenance & 7 & 7 & 8 & 9 & 6 & 4 & 6 & 8 & 6.7 & 1.485 & 4 & 9 & 5 \\
\hline Ergon. and Human Factors & 7 & 5 & 6 & 8 & 8 & 9 & 8 & 9 & 7.2 & 1.278 & 5 & 9 & 4 \\
\hline Automation & 10 & 10 & 11 & 10 & 10 & 10 & 10 & 10 & 10.1 & 0.350 & 10 & 11 & 1 \\
\hline Industrial Optimization & 11 & 11 & 10 & 11 & 11 & 11 & 10 & 11 & 10.7 & 0.452 & 10 & 11 & 1 \\
\hline
\end{tabular}

\subsection{Transversal competences}

The references to transversal competences in the 1,391 job advertisements were analyzed considering two interrelated phases: content analysis for an emergent identification of transversal competences referred by employers; and computing of frequency to be used as an indicator of importance of the identified transversal competences for employers. The graph in Figure 2 presents both the 2007-2013 cumulative frequency of referred transversal competences in the 1,391 job advertisements, and the relative frequency of the same transversal competences (TRC). The measures presented in "Total \%" in Figure 2 have a margin of error from $\pm 0.1 \%$ to $\pm 1.0 \%$, respectively from Ethics to Foreign Languages, with a confidence level of 95\%.

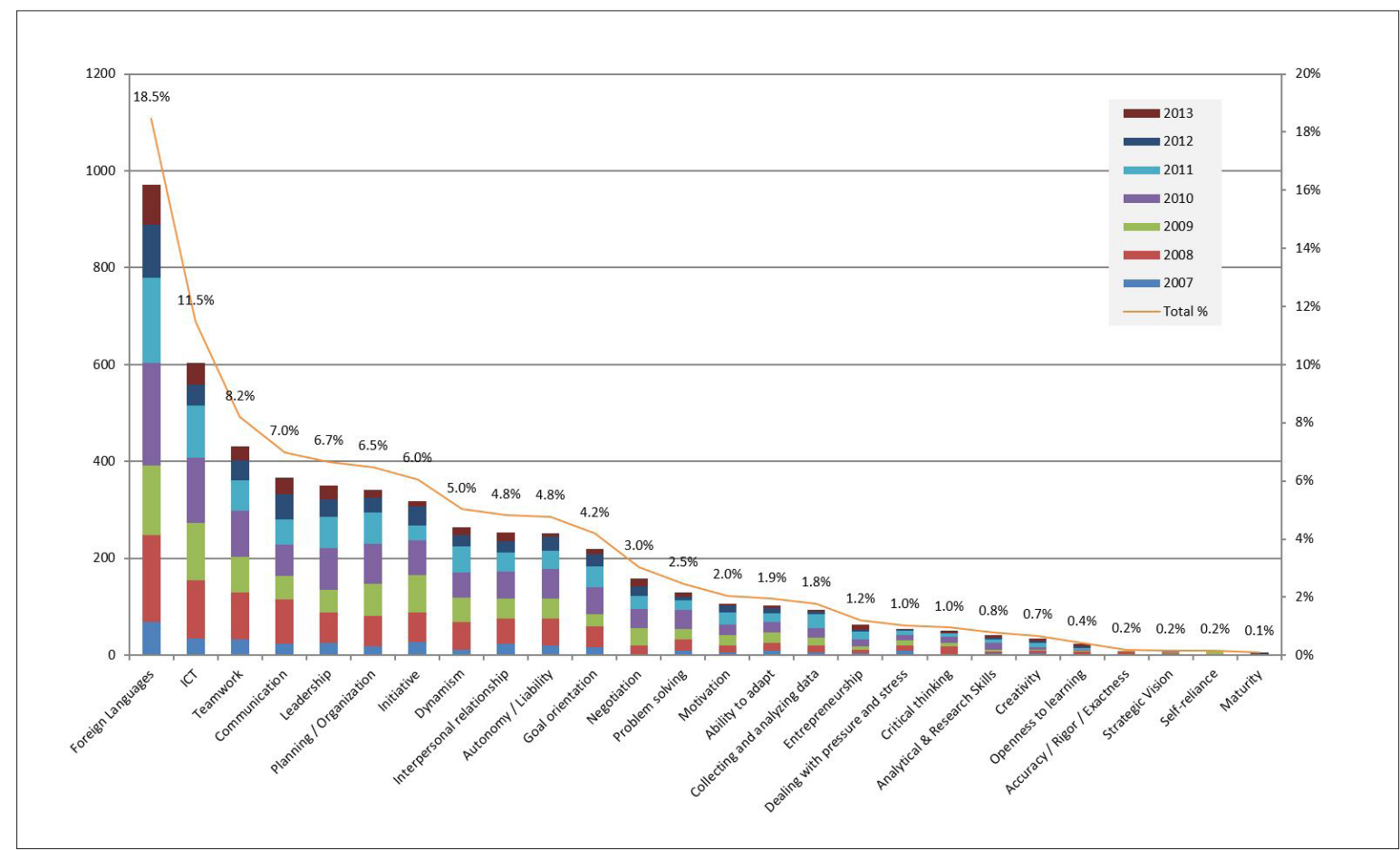

Figure 2. Job advertisements analysis: transversal competences.

The most important TRC is the foreign language (18.5\%), and in this case employers are referring most of the times to the English language. Although this is predominantly relevant for countries that are non-English speaking countries, the globalization makes an increased stress for engineers that have domain of a non- native speaking language and implies that engineers need to integrate multicultural teams (Greene, 2001; Oladiran et al., 2011). Furthermore, this reinforces the importance of other transversal competences, such as working in teams, communicating with other professionals at different levels, and adapting to different contexts and situations. 
The next TRC valued by employers is Information and Communication Technology with $11.5 \%$ frequency percentage. Teamwork is a competence highly valued by employers (8.2\%) with more than 430 references. Immediately following these, it is possible to identify four TRC above $6.0 \%$, respectively Communication (7.0\%), Leadership (6.7\%), Planning / Organization (6.5\%) and Initiative (6.0\%). The analysis of the most valued competences by employers give important information for the development of curricula and the application of learning methodologies for IEM programs.

The TRCs with an almost negligible frequency, with percentages below $0.2 \%$, are Strategic Vision, Self-reliance, Maturity and Ethics. Ethics can be seen as a special case because it is referred by accreditation associations as a requisite for the professional practice (ABET, 2013; EUR-ACE, 2008). Considering this, Ethics can be seen as a competence that employers do not need to specifically refer in the job advertisement text. Nevertheless, Hodgson et al. (2013) indicate that this competence is not being developed as it should during the initial education.

Table 4 represents the rank of all TRCs during the 7 years. Even considering that rankings' results are highly sensible to small variations, it made possible to interpret the evolution in a way that was not possible with the direct evolution of seven years of data. The ranking data allowed to identify the high variable demand of transversal competences, which have a variation of 8 or more positions in ranking, respectively with variations of 8, 15, 10, 11, 8 and 8 positions: Initiative, Ability to adapt, Analytical \& Research Skills, Dealing with pressure and stress, Entrepreneurship, Critical thinking, and Creativity. Analytical \& Research Skills is a competence that gained importance during the last two years analyzed, being in position 7 of frequency of reference by employers in job advertisements in the last year analyzed. Dealing with pressure and stress had a stable position between 16 and 20 , and in the last analyzed year it was the $10^{\text {th }}$ most referred competence.

Table 4. Ranking of transversal competences.

\begin{tabular}{|c|c|c|c|c|c|c|c|c|c|c|c|c|c|}
\hline Job advertisements & 89 & 249 & 213 & 321 & 261 & 149 & 109 & & & & & & \\
\hline Number of cumulative references & 360 & 1034 & 890 & 1177 & 902 & 532 & 366 & & & & & & \\
\hline Transversal competences ranking & 2007 & 2008 & 2009 & 2010 & 2011 & 2012 & 2013 & TOT. & AVR. & STD & MIN & MAX & DIFF \\
\hline Foreign Languages & 1 & 1 & 1 & 1 & 1 & 1 & 1 & 1 & 1 & 0.00 & 1 & 1 & 0 \\
\hline 1CT & 2 & 2 & 2 & 2 & 2 & 3 & 2 & 2 & 2 & 0.35 & 2 & 3 & 1 \\
\hline Teamwork & 3 & 3 & 4 & 3 & 3 & 4 & 4 & 3 & 3 & 0.49 & 3 & 4 & 1 \\
\hline Planning / Organization & 6 & 4 & 7 & 7 & 7 & 2 & 3 & 4 & 5 & 1.96 & 2 & 7 & 5 \\
\hline Leadership & 5 & 5 & 8 & 4 & 4 & 6 & 5 & 5 & 5 & 1.28 & 4 & 8 & 4 \\
\hline Communication & 9 & 6 & 5 & 5 & 4 & 7 & 7 & 6 & 6 & 1.55 & 4 & 9 & 5 \\
\hline Initiative & 4 & 6 & 3 & 6 & 11 & 4 & 10 & 7 & 6 & 2.86 & 3 & 11 & 8 \\
\hline Autonomy / Liability & 11 & 8 & 6 & 11 & 6 & 10 & 9 & 8 & 9 & 1.98 & 6 & 11 & 5 \\
\hline Interpersonal relationship & 6 & 10 & 9 & 10 & 9 & 11 & 6 & 9 & 9 & 1.83 & 6 & 11 & 5 \\
\hline Dynamism & 8 & 9 & 9 & 8 & 10 & 8 & 14 & 10 & 9 & 1.99 & 8 & 14 & 6 \\
\hline Goal orientation & 10 & 11 & 12 & 9 & 8 & 9 & 10 & 11 & 10 & 1.24 & 8 & 12 & 4 \\
\hline Analytical \& Research Skills & 22 & 13 & 11 & 12 & 13 & 12 & 7 & 12 & 13 & 4.19 & 7 & 22 & 15 \\
\hline Negotiation & 12 & 12 & 13 & 12 & 15 & 15 & 13 & 13 & 13 & 1.24 & 12 & 15 & 3 \\
\hline Problem solving & 15 & 17 & 13 & 14 & 14 & 13 & 18 & 14 & 15 & 1.81 & 13 & 18 & 5 \\
\hline Motivation & 14 & 14 & 15 & 14 & 16 & 14 & 15 & 15 & 15 & 0.73 & 14 & 16 & 2 \\
\hline Ability to adapt & 15 & 16 & 16 & 16 & 12 & 16 & 21 & 16 & 16 & 2.45 & 12 & 21 & 9 \\
\hline Dealing with pressure $\&$ stress & 17 & 19 & 20 & 18 & 16 & 18 & 10 & 17 & 17 & 3.04 & 10 & 20 & 10 \\
\hline Entrepreneurship & 12 & 18 & 17 & 20 & 18 & 22 & 23 & 18 & 19 & 3.37 & 12 & 23 & 11 \\
\hline Critical thinking & 20 & 15 & 18 & 19 & 21 & 23 & 18 & 19 & 19 & 2.35 & 15 & 23 & 8 \\
\hline Creativity & 17 & 23 & 21 & 17 & 20 & 20 & 15 & 20 & 19 & 2.56 & 15 & 23 & 8 \\
\hline Openness to learning & 17 & 22 & 22 & 21 & 19 & 16 & 15 & 21 & 19 & 2.69 & 15 & 22 & 7 \\
\hline Accuracy / Rigor / Exactness & 23 & 19 & 24 & 22 & 22 & 18 & 18 & 22 & 21 & 2.29 & 18 & 24 & 6 \\
\hline Strategic Vision & 23 & 19 & 22 & 24 & 25 & 24 & 24 & 23 & 23 & 1.85 & 19 & 25 & 6 \\
\hline Self-reliance & 20 & 24 & 24 & 22 & 23 & 24 & 24 & 24 & 23 & 1.41 & 20 & 24 & 4 \\
\hline Maturity & 23 & 24 & 18 & 24 & 25 & 24 & 24 & 25 & 23 & 2.17 & 18 & 25 & 7 \\
\hline Ethics & 23 & 26 & 26 & 24 & 23 & 20 & 22 & 26 & 23 & 1.99 & 20 & 26 & 6 \\
\hline
\end{tabular}

Regarding the evolution during the years, the competences' ranking in positions 1, 2 and 3 are very stable regarding the rank variation. Even considering the error of $\pm 1.0 \%, 0.9 \%$ and $0.7 \%$, of the relative frequency of the transversal competences measured (Figure 2), they would be consistent in the same first positions.

With the analysis of ranking variation, not only is it possible to find out which competences are related to IEM practice, but also it is an important input for defining the IEM professional profile. The transversal competences 
are not more important than technical ones, but both need to be included in engineering programs, in order to prepare graduates considering what the IEM practice requires.

\section{Conclusion}

The UNESCO (United Nations Educational, Scientific and Cultural Organization, 2010) report states the importance to identify and explore the main issues and challenges that engineering is facing, including the need for better understanding of what engineering is and what engineers do; how many engineers a country or industry needs and in which areas and levels; and how this reflects in a change on the engineering education. This work contributes for understanding what IEM is and what these engineers do.

The perceptions about IEM are variable but mainly focused on the analysis, design, and management of production systems. Nevertheless, this general perspective is not enough to characterize the professional practice and as a consequence, it is not enough to understand what these engineers should be capable of doing. As Kotnour (2013, p. 5-6) argue, engineering management researchers should contribute for the clarification of engineering management knowledge and in that way support other engineers to solve problems.

In looking at the grand challenges identified by the National Academy of Engineering, we see that there is plenty more to do. Engineers will continue to make the world a better place. Our role as engineering managers is to help make this possible. Our role as engineering management researchers is to help produce the knowledge and engineering leaders to address these grand challenges. The challenges will not be solved by technology alone. Organizations and teams will need to be run well in order to produce the results we desire.

In this work, an analysis of the professionals' perspective of areas of practice and transversal competences was conducted, considering job advertisements. This picture can be used as one possible input for engineering professionals to understand the market trends within the diversity of areas presented in IEM. For instance: according to the findings, Supply Chain Management is a professional practice area that has been growing in the last years. This could be a useful indicator to define industrial strategies or professional development.

This picture also provides an important contribution for IEM Education, through evaluation and design course programs, to give an adequate level of formation in different technical areas. Additionally, the transversal competences analysis shows an increased need for teaching and learning strategies that can promote the development of selected competences. Therefore, it is necessary to continuously improve the education system based on student-centered approaches including active learning methods, such as problem and project based learning, games, case studies and peer instruction. According to Kolmos \& Holgaard (2010, p. 575), "[...] an educational strategy for innovation and its value to employability within engineering profession". This study contributes for the rationale of innovation in Engineering Management Education, providing an overview of the areas of practice and the transversal competences needed in professional contexts. The Engineering Management curricula focus on specific content of an area that will be important for practice, for instance Enterprise Resources Planning in Production Planning and Control or Six Sigma for Quality. However, the findings show that the professional practice implies more than technical knowledge. The transversal competences are also important; however they do not have enough space in curricula. Several authors have been discussing how transversal competences can be taught in engineering contexts (Pascail, 2006; Rosenberg et al., 2012; Shuman et al., 2005). Martin et al. (2005, p. 179) suggest that "[...] non-technical skills cannot be taught isolated from technical context in which they will be used". In this sense, it is essential to promote learning strategies that combine technical knowledge and transversal competences. There are several studies showing that in active learning contexts students are able to develop both competences in an integrated way (Fastré et al., 2013; Fernandes et al., 2014; Jackson, 2012; Mesquita et al., 2013; Moesby, 2005; Santandreu-Mascarell et al., 2011; Van Hattum-Janssen \& Mesquita, 2011).

A change like this could also consider real situations as learning opportunities if the right cooperation between universities and companies are built. For example, real companies' problems could be used as students' projects functioning as a real situation learning opportunity, where students need to deal with the complexities of professional practice as mentioned in the report "Educating the Engineer of 2020" (National Academy of Science, 2005).

A further step for improvement of course programs requires adequate tools for analysis and representation of its relationship with the desired professional profiles, such as a tool that could be used to identify the gap between academia and companies, contributing for a curriculum (re)design that reduces that gap and creates the appropriate learning environment for the students, in order to qualify engineers with a profile closer to the needs of the professional practice. The professionals' perspectives have been increasingly considered an added 
value for curriculum review and innovation (Evans et al., 1993; Meier et al., 2000; Pascail, 2006; Sageev \& Romanowski, 2001; Scott \& Yates, 2002).

Future work is expected to be done in more countries in order to create a comparison between different contexts and cultures, extending the method of data collection and analysis, and developing a wider picture of Engineering Management field based on differences and similarities identified in different contexts. This research can also contribute to narrow the number of transversal competences that are required for the characterization of the area, and to establish a continuous and dynamic observatory in the field. These contributions are essential to map and link the educational context of engineer managers to what is expected in professional practice.

\section{Acknowledgements}

This work was partially funded by COMPETE-POCl-01-0145-FEDER-007043 and FCT-UID-CEC-00319-2013.

\section{References}

ABET. (2013). Criteria for accrediting engineering programs: effective for reviews during the 2014-2015 accreditation cycle. Baltimore. Retrieved in 2 December 2016, from http://www.abet.org/eac-criteria-2014-2015/

American Society for Quality - ASQ. (2016). Quality engineering: quality glossary by the American Society for Quality. Retrieved in 2 December 2016, from http://asq.org/glossary/q.html

APICS. (2009). APICS Operations Management Body of Knowledge Framework (OMBOK) (2nd ed.). Chicago: APICS.

APICS. (2013a). Design: APICS dictionary (14th ed.). Chicago: APICS.

APICS. (2013b). Marketing: APICS dictionary (14th ed.). Chicago: APICS.

APICS. (2013c). Optimization: APICS dictionary (14th ed.). Chicago: APICS.

APICS. (2013d). Supply Chain Management: APICS dictionary (14th ed.). Chicago: APICS.

Bangert, P. (2012). Optimization for industrial problems. Heidelberg: Springer-Verlag. http://dx.doi.org/10.1007/978-3-642-24974-7.

Bardin, L. (2006). Análise de conteúdo. Lisboa: Edições 70.

Becker, F. S. (2006). Globalization, curricula reform and the consequences for engineers working in an international company. European Journal of Engineering Education, 31(3), 261-272. http://dx.doi.org/10.1080/03043790600644749.

Biesma, R. G., Pavlova, M., Vaatstra, R., van Merode, G. G., Czabanowska, K., Smith, T., \& Groot, W. (2008). Generic versus specific competencies of entry-level public health graduates: employers' perceptions in Poland, the UK, and the Netherlands. Advances in Health Sciences Education: Theory and Practice, 13(3), 325-343. PMid:17151830. http://dx.doi.org/10.1007/s10459-006-9044-0.

Biggs, J., \& Tang, C. (2011). Teaching for quality learning at University. New York: McGraw-Hill Education.

Buzacott, J. A. (1984). The future of industrial engineering as an academic discipline. IIE Transactions, 16(1), 35-43. http://dx.doi. org/10.1080/07408178408974665.

CEDEFOP. (2012). Skill mismatch: the role of the enterprise. Thessaloniki. Retrieved in 2 December 2016, from http://www.cedefop. europa.eu/EN/Files/5521_en.pdf

Dym, C. L., Little, P., \& Orwin, E. J. (2014). Engineering design: a project-based introduction (4th ed.). Hoboken: John Wiley \& Sons.

El-Baz, H. S., \& El-Sayegh, S. M. (2010). Competency domain model and the perception of engineering managers in the United Arab Emirates. Engineering Management Journal, 22(1), 3-12. http://dx.doi.org/10.1080/10429247.2010.11431848.

Elrod, C. C., Daughton, W. J., Murray, S. L., \& Flachsbart, B. B. (2010). Evaluating the Engineering Management Brand Meaning. Engineering Management Journal, 22(2), 16-26. http://dx.doi.org/10.1080/10429247.2010.11431860.

Elsayed, E. A. (1999). Industrial engineering education: a prospective. European Journal of Engineering Education, $24(4), 415-421$. http://dx.doi.org/10.1080/03043799908923576.

Emerson, H. P., \& Naehring, D. C. E. (1988). Origins of industrial engineering: the early years of a profession. Norcross: Industrial Engineering \& Management Press, Institute of Industrial Engineers.

Esteves, M. (2006). Análise de conteúdo. In J. A. Lima \& J. A. Pacheco (Eds.), Fazer investigação: xontributos para a elaboração de dissertação e teses (pp. 105-126). Porto: Porto Editora.

EUR-ACE. (2008). EUR-ACE framework standards for the accreditation of engineering programmes. Retrieved in 2 December 2016, from http://www.ihep.org/assets/files/gcfp-files/EUR-ACESTANDARDS.pdf

European_Commission. (2007). Modernising universities: summaries of EU legislation. Retrieved in 2 December 2016, from http://eurlex.europa.eu/legal-content/EN/TXT/?qid=1432585582363\&uri=URISERV:c11089

Evans, D. L., Beakley, G. C., Crouch, P. E., \& Yamaguchi, G. T. (1993). Attributes of engineering graduates and their impact on curriculum design. Journal of Engineering Education, 82(4), 203-211. http://dx.doi.org/10.1002/j.2168-9830.1993.tb01075.x.

Expresso. (2015, October 29). Expresso cresce 5,6\% em circulação paga: Expresso reforça liderança na imprensa semanal e é o jornal com mais circulação digital paga em Portugal. Expresso. Retrieved in 2 December 2016, from http://expresso.sapo.pt/sociedade/201510-29-Expresso-cresce-56-em-circulacao-paga

Fastré, G. M. J., Van der Klink, M. R., Sluijsmans, D., \& Van Merriënboer, J. J. G. (2013). Towards an integrated model for developing sustainable assessment skills. Assessment \& Evaluation in Higher Education, 38(5), 611-630. http://dx.doi.org/10.1080/02602938 .2012 .674484 .

Fernandes, S., Mesquita, D., Flores, M. A., \& Lima, R. M. (2014). Engaging students in learning: findings from a study of project-led education. European Journal of Engineering Education, 39(1), 55-67. http://dx.doi.org/10.1080/03043797.2013.833170. 
Fraser, J., \& Teran, A. (2006). Benchmarking International Industrial Engineering Programs. In Proceedings of the American Society for Engineering Education Annual Conference \& Exposition, Washington.

Gallwey, T. J. (1992). Europe needs industrial engineering degrees in order to enhance its competitiveness. European Journal of Engineering Education, 17(1), 51-57. http://dx.doi.org/10.1080/03043799208923155.

González, J., \& Wagenaar, R. (Eds.). (2007). Tuning Project Report: general brochure final version. Espanha: Universidad de Deusto. Retrieved in 2 December 2016, from http://www.unideusto.org/tuningeu/images/stories/documents/General_Brochure_final_version.pdf

Greene, T. (2001). The future of industrial engineering: one perspective. In K. B. Zandin (Ed.), Maynard's Industrial Engineering Handbook (5th ed., pp. 1.97-109). New York: McGraw Hill.

Groover, M. P. (2015). Automation, production systems, and computer-integrated manufacturing (4th ed.). New Jersey: Pearson.

Halász, G., \& Michel, A. (2011). Key competences in Europe: interpretation, policy formulation and implementation. European Journal of Education, 46(6), 289-306. http://dx.doi.org/10.1111/j.1465-3435.2011.01491.x.

Halevi, G. (2001). Handbook of production management methods. Oxford: Butterworth-Heinemann.

Hattum-Janssen, N., \& Mesquita, D. (2011). Teacher perception of professional skills in a project-led engineering semester. European Journal of Engineering Education, 36(5), 461-472. http://dx.doi.org/10.1080/03043797.2011.606501.

Healy, A., Perkmann, M., Goddard, J., \& Kempton, L. (2014). Measuring the impact of university-business cooperation: final report. Retrieved in 2 December 2016, from http://bookshop.europa.eu/en/measuring-the-impact-of-university-business-cooperation-pbNC0214337/

Heijde, C. M. V. D., \& Van Der Heijden, B. I. J. M. (2006). A competence-based and multidimensional operationalization and measurement of employability. Human Resource Management, 45(3), 449-476. http://dx.doi.org/10.1002/hrm.20119.

Hennemann, S., \& Liefner, 1. (2010). Employability of german geography graduates: the mismatch between knowledge acquired and competences required. Journal of Geography in Higher Education, 34(2), 215-230. http://dx.doi.org/10.1080/03098260903227400.

Hicks, P. E. (2001). Fundamentals of industrial engineering. In K. B. Zandin (Ed.), Maynard's industrial engineering handbook (5th ed., pp. 1.85-94). New York: McGraw Hill.

Hodgson, Y., Varsavsky, C., \& Matthews, K. E. (2013). Assessment and teaching of science skills: whole of programme perceptions of graduating students. Assessment \& Evaluation in Higher Education, 39(5), 515-530. http://dx.doi.org/10.1080/02602938.2013.842539.

IDCON. (2016). Maintenance dictionary. Retrieved in 2 December 2016, from http://www.idcon.com/resource-library/maintenancedictionary.html

Institute of Industrial Engineers - llE. (2012). About llE. Retrieved in 2 December 2016, from http://www.iienet2.org/Details.aspx?id=282

International Ergonomics Association - IEA. (2016). Definition and domains of ergonomics by the International Ergonomics Association. Retrieved in 2 December 2016, from http://www.iea.cc/whats/index.html

Jackson, D. (2012). Testing a model of undergraduate competence in employability skills and its implications for stakeholders. Journal of Education and Work, 27(2), 220-242. http://dx.doi.org/10.1080/13639080.2012.718750.

Knight, P., \& Yorke, M. (2004). Learning, curriculum and employability in higher education. New York: Routledge.

Kolmos, A., \& Holgaard, J. E. (2010). Responses to problem based and project organised learning from industry. International Journal of Engineering Education, 26(3), 573-583.

Kotnour, T. (2013). Why EMJ? Engineering Management Journal, 25(4), 5-6. http://dx.doi.org/10.1080/10429247.2013.11431990.

Kotnour, T., \& Farr, J. V. (2005). Engineering management: past, present, and future. Engineering Management Journal, 17(1), 15-26. http://dx.doi.org/10.1080/10429247.2005.11415273.

Kuo, W. (2001). Educational Programs for the Industrial Engineer. In K. B. Zandin (Ed.), Maynard's Industrial engineering handbook (5th ed., pp. 1.39-53). New York: McGraw Hill.

Le Boterf, G. (1997). De la compétence à la navigation professiionelle. Paris: Les Éditions d'Organisation.

Léger, P. M., Cronan, P., Charland, P., Pellerin, R., Babin, G., \& Robert, J. (2012). Authentic OM problem solving in an ERP context. International Journal of Operations \& Production Management, 32(12), 1375-1394. http://dx.doi.org/10.1108/01443571211284151.

Lima, R. M., Mesquita, D., Amorim, M., Jonker, G., \& Flores, M. A. (2012). An analysis of knowledge areas in industrial engineering and management curriculum. International Journal of Industrial Engineering and Management, 3(2), 75-82.

Lima, R. M., Mesquita, D., \& Flores, M. A. (2014). Project Approaches in Interaction with Industry for the Development of Professional Competences. In Proceedings of the Industrial and Systems Engineering Research Conference (ISERC 2014), Montréal, Canada.

Linton, 1. (2015). What is a job advertisement? Retrieved in 2 December 2016, from http://work.chron.com/job-advertisement-6654.html

Marie-Emmanuelle, A., Michèle, B., Véronique, P., Jean, F., \& lon, l. (2010). Student's Quality of Life and Employability Skills: SQALES, un dispositif et un instrument au service des universités. Exemple d'utilisation au Luxembourg, en Belgique et en Roumanie. Revista de Cercetare si Interventie Sociala, 28, 97-114.

Markes, 1. (2006). A review of literature on employability skill needs in engineering. European Journal of Engineering Education, 31(6), 637-650. http://dx.doi.org/10.1080/03043790600911704.

Martin, R., Maytham, B., Case, J., \& Fraser, D. (2005). Engineering graduates' perceptions of how well they were prepared for work in industry. European Journal of Engineering Education, 30(2), 167-180. http://dx.doi.org/10.1080/03043790500087571.

Martin-Vega, L. (2001). The purpose and evolution of industrial engineering. In K. B. Zandin (Ed.), Maynard's industrial engineering handbook (5th ed., pp. 1.3-1.19). New York: McGraw Hill.

Mason, G., Williams, G., \& Cranmer, S. (2009). Employability skills initiatives in higher education: what effects do they have on graduate labour market outcomes? Education Economics, 17(1), 1-30. http://dx.doi.org/10.1080/09645290802028315.

Matson, J., Mozrall, J., Schaub, D., \& Patterson, P. (2007). An industrial engineering body of knowledge? In Proceedings of the American Society for Engineering Education Annual Conference \& Exposition, Washington.

Meier, R. L., Williams, M. R., \& Humphreys, M. A. (2000). Refocusing our efforts: assessing non-technical competency gaps. Journal of Engineering Education, 89(3), 377-385. http://dx.doi.org/10.1002/j.2168-9830.2000.tb00539.x.

Mertens, L. (1996). Competencia laboral: sistemas, surgimiento y modelos. Montevideo: Cinterfor. 
Mesquita, D., Lima, R. M., \& Flores, M. A. (2013). Developing professional competencies through projects in interaction with companies: a study in industrial engineering and management master degree. In Proceedings of the Fifth International Symposium on Project Approaches in Engineering Education (PAEE'2013): Closing the Gap between University and Industry, Eindhoven, The Netherlands.

Mesquita, D., Lima, R. M., Flores, M. A., Marinho-Araujo, C., \& Rabelo, M. (2015). Industrial engineering and management curriculum profile. Developing a Framework of Competences International Journal of Industrial Engineering and Management, 6(3), $121-131$.

Miles, M., \& Huberman, A. (1994). Qualitative data analysis: an expanded sourcebook (2nd ed.). Thousand Oaks: Sage.

Moesby, E. (2005). Curriculum development for project-oriented and problem-based learning (popbl) with emphasis on personal skills and abilities. Global Journal of Engineering Education, 9(2), 121-128.

Nair, C., Patil, A., \& Mertova, P. (2009). Re-engineering graduate skills: a case study. European Journal of Engineering Education, 34(2), 131-139. http://dx.doi.org/10.1080/03043790902829281.

National Academy of Science - NAE. (2005). Educating the Engineer of 2020: adapting engineering education to the new century. Washington. Retrieved in 2 December 2016, from http://www.nap.edu/openbook.php?record_id=11338

Oladiran, M. T., Uziak, J., Eisenberg, M., \& Scheffer, C. (2011). Global engineering teams: a programme promoting teamwork in engineering design and manufacturing. European Journal of Engineering Education, 36(2), 173-186. http://dx.doi.org/10.1080/0 3043797.2011.573534.

Omurtag, Y. (2009). What is engineering management? A new look at an old question. Engineering Management Journal, $21(4), 3-6$. http://dx.doi.org/10.1080/10429247.2009.11431839.

Pascail, L. (2006). The emergence of the skills approach in industry and its consequences for the training of engineers. European Journal of Engineering Education, 31(1), 55-61. http://dx.doi.org/10.1080/03043790500428965.

Passow, H. J. (2012). Which ABET competencies do engineering graduates find most important in their work? Journal of Engineering Education, 101(1), 95-118. http://dx.doi.org/10.1002/j.2168-9830.2012.tb00043.x.

Perrenoud, P. (2004). De uma metáfora a outra: transferir ou mobilizar conhecimentos? In J. Dolz \& E. Ollagnier (Eds.), $O$ enigma da competência em educação (pp. 47-63). Porto Alegre: Artmed.

Pesches, K., \& Reindel, E. (1998). Project-oriented engineering education to improve key competencies. Global Journal of Engineering Education, 2(2), 181-186.

Project Management Institute. (2013). PMBOK ${ }^{\circledR}$ guide: a guide to the project management body of knowledge (5th ed.). Pennsylvania: PM1.

Ramesh, G. (2010). The ace of soft skills: attitude, communication and etiquette for success. India: Pearson Education.

Ranga, M., Hoareau, C., Durazzi, N., Etzkowitz, H., Marcucci, P., \& Usher, A. (2013). Study on University-Business Cooperation in the US. London: LSE. Retrieved in 2 December 2016, from http://www.lse.ac.uk/businessAndConsultancy/LSEEnterprise/pdf/UBC-Finalreport-May2013.pdf

Rees, C., Forbes, P., \& Kubler, B. (2006). Student employability profiles: a guide for higher education practitioners. York: Higher Education Academy. Retrieved in 2 December 2016, from http://www.heacademy.ac.uk/assets/documents/employability/student_ employability_profiles_apr07.pdf

Rosenberg, S., Heimler, R., \& Morote, E.-S. (2012). Basic employability skills: a triangular design approach. Education + Training, 54(1), 7-20. http://dx.doi.org/10.1108/00400911211198869.

Sabochik, K. (2010). Building Skills for America's Future. Retrieved in May 10, 2017, from https://obamawhitehouse.archives.gov/ blog/2010/10/04/building-skills-america-s-future

Sageev, P., \& Romanowski, C. J. (2001). A message from recent engineering graduates in the workplace: results of a survey on technical communication skills. Journal of Engineering Education, 90(4), 685-693. http://dx.doi.org/10.1002/j.2168-9830.2001.tb00660.x.

Sampieri, R., Collado, C., \& Lucio, P. (2006). Metodologia de pesquisa (3rd ed.). São Paulo: McGraw-Hill.

Santandreu-Mascarell, C., Canós-Darós, L., \& Pons-Morera, C. (2011). Competencies and skills for future Industrial Engineers defined in Spanish degrees. Journal of Industrial Engineering and Management, 4(1), 13-30. http://dx.doi.org/10.3926/jiem.2011.v4n1.p13-30.

Santos, L. C., Gohr, C. F., \& Vieira Junior, M. (2012). Simulation of assembly operations using interchangeable parts for OM education: A hands-on activity with water pipe fittings. International Journal of Operations \& Production Management, 32(12), 1427-1440. http://dx.doi.org/10.1108/01443571211284179.

Scott, G., \& Yates, K. W. (2002). Using successful graduates to improve the quality of undergraduate engineering programmes. European Journal of Engineering Education, 27(4), 363-378. http://dx.doi.org/10.1080/03043790210166666.

Shuman, L. J., Besterfield-Sacre, M., \& McGourty, J. (2005). The ABET "professional skills": can they be taught? Can they be assessed? Journal of Engineering Education, 94(1), 41-55. http://dx.doi.org/10.1002/j.2168-9830.2005.tb00828.x.

Stiwne, E., \& Jungert, T. (2010). Engineering students' experiences of transition from study to work. Journal of Education and Work, 23(5), 417-437. http://dx.doi.org/10.1080/13639080.2010.515967.

Study.com. (2016). Automation engineering course and class descriptions. Retrieved in 2 December 2016, from http://study.com/ automation_engineering_course.html

Tymon, A. (2013). The student perspective on employability. Studies in Higher Education, 38(6), 841-856. http://dx.doi. org/10.1080/03075079.2011.604408.

United Nations Educational, Scientific and Cultural Organization - UNESCO. (2010). Engineering: issues, challenges and opportunities for development. France: UNESCO. Retrieved in 2 December 2016, from http://unesdoc.unesco.org/images/0018/001897/189753e.pdf

University-Business Cooperation. (2017). University-Business Cooperation in Europe. Retrieved in 10 May 2017, from https://www. ub-cooperation.eu

Van Hattum-Janssen, N., \& Mesquita, D. (2011). Teacher perception of professional skills in a project-led engineering semester. European Journal of Engineering Education, 36(5), 461-472. http://dx.doi.org/10.1080/03043797.2011.606501.

Vollmann, T. E., William, L. B., Whybark, D. C., \& Jacobs, F. R. (2005). Manufacturing planning and control for supply chain management (5th ed.). New York: McGraw-Hill. 
Walther, J., Kellam, N., Sochacka, N., \& Radcliffe, D. (2011). Engineering competence? An interpretive investigation of engineering students' professional formation. Journal of Education and Work, 100(4), 703-740.

Watts, J. M., \& Chapman, R. E. (2016). Engineering economics. In J. M. Hurley, T. D. Gottuk, R. J. Hall Junior, K. Harada, D. E. Kuligowski, M. Puchovsky, L. J. Torero, M. J. Watts Junior, \& J. C. Wieczorek (Eds.), SFPE handbook of fire protection engineering (pp. 3137-3157). New York: Springer.

Yalabik, B., Howard, M., \& Roden, S. (2012). The innovation game: lessons in strategy and managing operations. International Journal of Operations \& Production Management, 32(12), 1441-1459. http://dx.doi.org/10.1108/01443571211284188.

Yorke, M. (2004). Employability in higher education: what it is - what it is not. York: The Higher Education Academy. Retrieved in 2 December 2016, from http://www.employability.ed.ac.uk/documents/Staff/HEA-Employability_in_HE\%28ls,lsNot\%29.pdf

Zandin, K. B. (Ed.). (2001). Maynard's industrial engineering handbook (5th ed.). New York: McGraw Hill.

Zarifian, P. (2001). Objetivo competência. por uma nova lógica. São Paulo: Atlas.

Received: Dec. 2, 2016

Accepted: May 15, 2017 